\title{
Seaweed Pretreatment of Chickpea (Cicer arietinum) Enhances Post Harvest Preservation by Reducing Germination
}

Ritisha D Viththalpara ${ }^{1}$, Ajaaj R Saiyad ${ }^{1}$, Asha J Jani' ${ }^{1}$, Dipesh R Vara ${ }^{1}$, Prashant D Kunjadia ${ }^{2}$, Gaurav V Sanghvi ${ }^{3,4}$, Devendra Vaishnav ${ }^{3}$ and Gaurav S Dave ${ }^{1 *}$

${ }^{1}$ Department of Biochemistry, Saurashtra University, Rajkot, India

${ }^{2} B$ N Patel Institute of Paramedical Sciences, Bhalej Road, Anand, India

${ }^{3}$ Department of Pharmaceutical Sciences, Saurashtra University, Rajkot, India

${ }^{4}$ Max Planck Institute of Developmental Biology, Tubingen, Germany

\begin{abstract}
The plant growth enhancer property of seaweeds has been studied in different crops. Seaweed (Sargassum wightii and Uluva lectuca) were collected from costal region of Mangrol and studied for its effect on germination and storage of chickpea. Chickpea seeds were soaked in $1 \%$ seaweed extracts for $6 \mathrm{~h}$ and dried at room temperature before sowing for germination in the soil. Percentage of seeds germination was less in S. wightii (67\%) and $U$. lectuca $(65 \%)$ treated seeds as compared to control. Furthermore, the treatment also prolonged germination time as compared to untreated control. Seaweed extracts effects on seeds viability upon longer storage was affected by the storage conditions. For instance, storage of seeds treated with seaweeds extracts at room temperature was more affected as compared to $4-8^{\circ} \mathrm{C}$ and $-20^{\circ} \mathrm{C}$. These results showed that seaweed extract is possible to use for increasing post harvest shelf life of chickpea without affecting its natural texture.
\end{abstract}

Keywords: Seaweed; Chickpea; Longevity; Germination

\section{Introduction}

Seaweed is natural and domestic resource of plant growth promoter also in the Gujarat coastal region. Seaweed has been used to enhance the growth and germination of various plants (8-13). Seaweeds like Sargassum, Ulva, Caulerpa, Padina, Ecklonia have been found to contain essential micronutrients such as potassium, zinc, molybdenum, nitrogen, copper, cobalt, etc. [1-3] as well as plant growth hormones like IAA, gibberellins, abscisic acid, auxins and other important phytochemical that support the growth and development of plants [4-7]. Many species of seaweeds have been found to stimulate the defense responses in the plants [8]. Many seaweeds have also been reported as a food ingredients and supplements [9-11].

Chickpea (Cicer arietinum L.) is one of most important pulse crops in the world. According to world Food and Agriculture Organization (FAO) survey published in 2011, India contributes $68 \%$ of global production of chickpea [12]. Total estimate of chickpea production has gone up to around 8567.8 thousand tones in the year 2013-14. Post harvest preservation of green chickpea is one of the hurdle that limits the full exploitation of this crop potential both in sustainable serving to people and in contributing to agriculture economy of the country as well as inaccessible warehouse facility, whereas some of them are accessible only in fair weather [13]. Therefore, a technology that provides a sustainable and reliable means for the post harvest storage of chickpea would be worth inventing. The present study reports findings that may prove to be beneficial in storage of chickpea for longer time. We have exploited the usefulness of seaweed known as plant growth promoter in post harvest of chickpea. We found that extracts of seaweeds could reduce germination, increased shelf life without altering the natural texture of chickpea.

\section{Materials and Methods}

\section{Collection of seaweeds and preparation of cell free extracts}

Two seaweeds Sargassum wightii and Uluva lectuca used in the present study were collected from the coast of Mangrol $\left(21.1200^{\circ} \mathrm{N}\right.$, $70.1200^{\circ} \mathrm{E}$ ), Junagadh District, Gujarat, India in last week of January,
2014. These were washed thoroughly with seawater to remove all the unwanted impurities including sediments, salts and macroscopic epiphytes. Samples were kept in an ice box during transportation. Samples were rinsed with sterile water and dried on Whatman $3 \mathrm{MM}$ blotting paper under shadow seven days followed by hot air oven for $24 \mathrm{~h}$ at $40^{\circ} \mathrm{C}$. Dried seaweed samples were grounded to powder and 5 g powder was suspended in $500 \mathrm{ml}$ of sterile phosphate buffered saline. Extract was allowed to settle down and supernatant was passed through four layers of muslin cloth. The extract was stored at low temperature and thawed before seed treatment.

\section{Seed treatment with seaweed extracts and monitoring of germination}

Chickpea seeds were soaked in aqueous extracts of $S$. wightii or $U$. lectuca for $6 \mathrm{~h}$ and dried at room temperature. These were sowed in soil around $0.5 \mathrm{~cm}$ deep and watered regularly. Control Chickpea seeds were soaked in sterile phosphate buffered saline. Seed germination was confirmed by observation of two primary leaves. For monitoring the effect of storage conditions on seed germination, the chickpea seeds were soaked in aqueous extracts of S. wightii or U. lectuca for $1 \mathrm{~h}$ and dried at room temperature. These seeds were kept for 10 days in room or $-20^{\circ} \mathrm{C}$ deep freezer or $4-8^{\circ} \mathrm{C}$ refrigerator or open terrace in open petri-plates or in air tight plastic bag. Untreated seeds were also processed in parallel as control.

*Corresponding author: Gaurav S Dave, Assistant Professor, Department of Biochemistry, Saurashtra University, Rajkot-360 005, Gujarat, India, Tel: 094-282758-94; E-mail: gsdspu@gmail.com/gsdave@sauuni.ernet.in

Received September 15, 2015; Accepted October 26, 2015; Published October 30, 2015

Citation: Viththalpara RD, Saiyad AR, Jani AJ, Vara DR, Kunjadia PD, et al (2015) Seaweed Pretreatment of Chickpea (Cicer arietinum) Enhances Post Harvest Preservation by Reducing Germination. J Bioprocess Biotech 5: 257 doi:10.4172/2155-9821.1000257

Copyright: () 2015 Viththalpara RD, et al. This is an open-access article distributed under the terms of the Creative Commons Attribution License, which permits unrestricted use, distribution, and reproduction in any medium, provided the original author and source are credited. 


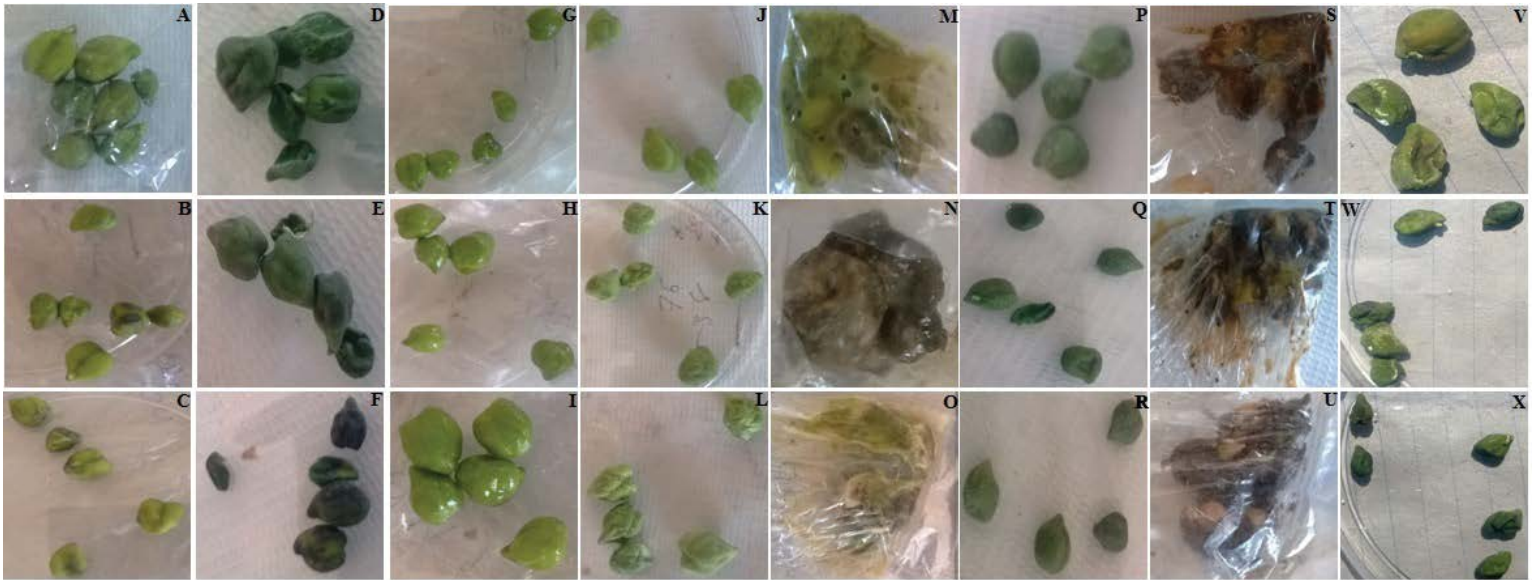

Figure 1: Effect of seaweed treatment at different temperature and packing on chickpea storage. A: Control in air tight bag at 4-8 ${ }^{\circ} \mathrm{C}$; $\mathrm{B}: \mathrm{S}$. wightii in air tight bag at $4-8^{\circ} \mathrm{C}$; C: U. lectuca in air tight bag at $4-8^{\circ} \mathrm{C}$; D: Control in open at $4-8^{\circ} \mathrm{C}$; $\mathrm{E}$ : S. wightii in open at $4-8^{\circ} \mathrm{C}$; $\mathrm{F}$ : U. lectuca in open at $4-8^{\circ} \mathrm{C}$; $\mathrm{G}$ : Control in air tight bag at $-20^{\circ} \mathrm{C}$; $\mathrm{H}$ : S. wightii in air tight bag at $-20^{\circ} \mathrm{C}$; I: $\mathrm{U}$. lectuca in air tight bag at $-20^{\circ} \mathrm{C}$; J: Control in open at $-20^{\circ} \mathrm{C}$; $\mathrm{K}: \mathrm{S}$. wightii in open at $-20^{\circ} \mathrm{C}$; L: $\mathrm{U}$. lectuca in open at $-20^{\circ} \mathrm{C}$; M: Control in air tight bag at room temperature; $\mathrm{N}$ : S. wightii in air tight bag at room temperature; O: U. lectuca in air tight bag at room temperature; P: Control in open at room temperature; Q: S. wightii in open at room temperature; R: U. lectuca in open at room temperature; S: Control in air tight bag in open terrace; T: S. wightii in air tight bag in open terrace; $\mathrm{U}$ : U. lectuca in air tight bag in open terrace; V: Control in open in open terrace; W: S. wightii in open in open terrace; $\mathrm{X}$ : $U$. lectuca in open in open terrace.

\section{Statistical analysis}

Data were analyzed using SPSS free trial version program and analysis of variance (ANOVA) was performed for result comparison among groups. Statistical property of results $\mathrm{p}<0.05$ was considered as significant.

\section{Results and Discussion}

Chickpea seeds treated with extract of seaweed delayed germination. Both the percentage of the seeds germinated and the time taken for germination were different from untreated controls. Seeds treated with S. wightii extract showed $67 \%(\mathrm{p}<0.05)$ germination and took 144 to $192 \mathrm{~h}$ to germinate in soil. The similar results were observed with $U$. lectuca extract treated seeds, $65 \%(\mathrm{p}<0.05)$ seeds were germinated after $144 \mathrm{~h}$ as compared to controls, which showed around $80 \%$ germination and could germinate within 24 to $72 \mathrm{~h}$.

The effect of seaweed as a preservative was evaluated and results are shown in Figure 1. Results showed that the seeds kept in open petriplate at $4^{\circ} \mathrm{C}$ become dark in color which was not observed when these were kept in air tight bag at the same temperature. or However, the seeds coated with seaweed (S. wightii and U. lectuca) developed dark spotted / patches at room temperature as well as $4^{\circ} \mathrm{C}$, whereas the chickpea seeds when kept at $-20^{\circ} \mathrm{C}$ temperature in air tight bag as well as in petri plates did not show any change at least in color. We also observed a striking difference in the texture. For example, seed kept in open were more wrinkled as compared to seeds kept in air tight bag. Looking into the results of Figure $1 \mathrm{M}, \mathrm{N}, \mathrm{O}, \mathrm{S}, \mathrm{T}$ and $\mathrm{U}$ chickpeas storage in air tight bag at room temperature as well in open environment leads to spoilage of seeds. Similarly, open container storage at room temperature and in open environment brings dryness/shrinkage and color darkness in seeds as shown in Figure $1 \mathrm{P}, \mathrm{Q}, \mathrm{R}, \mathrm{V}, \mathrm{W}$ and $\mathrm{X}$. Out of all studied groups chickpeas stored in air tight bag at $-20^{\circ} \mathrm{C}$ remained fresh and unspoiled without any changes in texture.

Seaweed liquid fertilizer prepared by various methods $[2,14-16]$ reported growth and germination stimulating effect $[2,15,16]$. We found contradictory results on pretreatment of chickpea seeds with seaweed extract, stimulates dormancy/delay in germination and decrease germination percentage, before sowing in field. Seaweed contains various plant growth regulators i.e., Indole acetic acid, abscisic acid, gibberellin, Indole butyric acid [14]. Abscisic acid exhibits dormancy effect on seed in contrast to gibberellin and Indole acetic acid, growth promoting activity. We treated seaweed extract in autoclave at $121^{\circ} \mathrm{C}$ and $15 \mathrm{lbs}$, which may be responsible for loss of stability of growth promoting factors, IAA and IBA stability is vulnerable under autoclaving [17], gibberellins decomposes under autoclaving and produces inhibitory products [18] whereas, anti-germinating factors could be remained unaltered, leads to delayed/anti-germinating effect on chickpea seeds.

We found chickpeas stored at room temperature or on open terrace either in air tight bag or in open container showed spoilage and wrinkled texture ultimately decreased longevity in comparison to seeds stored at $4-8^{\circ} \mathrm{C}$ and $-20^{\circ} \mathrm{C}$ temperature, our results are in support of earlier report regarding increasing temperature is responsible for high rate of loss of viability in chickpea seeds $[19,20]$. Moreover, seeds kept in open container showed darkness in color compared to seeds kept in air tight bag, whereas, least changes were found with the seeds stored at $-20^{\circ} \mathrm{C}$. These results indicate deleterious effect of high temperature and open container for storage of chickpeas.

In conclusion, autoclaved seaweed extract pretreatment to chickpea delays germination and temperature above $8^{\circ} \mathrm{C}$ and open container is not suitable for preservation of green chickpea irrespective of seaweed extract treatment.

\section{Acknowledgements}

Authors are thankful to Dr. Navin R Sheth for his help and guidance in field experiment.

\section{References}

1. el-Sheekh MM, el-Saied A el-D (2000) Effect of crude seaweed extracts on seed germination, seedling growth and some metabolic processes of Vicia faba L. Cytobios 101: 23-35.

2. Sivasankari S, Venkatesalu V, Anantharaj M, Chandrasekaran M (2006) Effect of seaweed extracts on the growth and biochemical constituents of Vigna sinensis. Bioresour Technol 97: 1745-1751. 
Citation: Viththalpara RD, Saiyad AR, Jani AJ, Vara DR, Kunjadia PD, et al. (2015) Seaweed Pretreatment of Chickpea (Cicer arietinum) Enhances Post Harvest Preservation by Reducing Germination. J Bioprocess Biotech 5: 257 doi:10.4172/2155-9821.1000257

Page 3 of 3

3. Hernández-Herrera RM, Santacruz-Ruvalcaba F, Ruiz-López MA, Norrie J Hernández-Carmona G (2014) Effect of liquid seaweed extracts on growth of tomato seedlings (Solanum lycopersicum L.). J Appl Phycol 26: 619-628.

4. Mooney PA, van Staden J (1986) Algae and cytokinins. J Plant Physiol 123: $1-21$.

5. Peña-Rodríguez A, Mawhinney TP, Ricque-Marie D, Cruz-Suárez LE (2011) Chemical composition of cultivated seaweed Ulva clathrata (Roth) C. Agardh. Food Chem 129: 491-498.

6. Stirk WA, Tarkowská D, Turecová V, Strnad M, van Staden J (2014) Abscisic acid, gibberellins and brassinosteroids in $\mathrm{Kelpak}^{\circledR}$, a commercial seaweed extract made from Ecklonia maxima. J Appl Phycol 26: 561-567.

7. Antonisamy JM, Essakimuthu P, Narayanan J, Anantham B, Tharmaraj RJJM, et al. (2012) Phytochemical characterization of brown seaweed Sargassum wightii. Asian Pac J Trop Dis 2: S109-S113.

8. Vera J, Castro J, Gonzalez A, Moenne A (2011) Seaweed polysaccharides and derived oligosaccharides stimulate defense responses and protection against pathogens in plants. Mar Drugs 9: 2514-2525.

9. Dillehay TD, Ramírez C, Pino M, Collins MB, Rossen J, et al. (2008) Monte Verde: seaweed, food, medicine, and the peopling of South America. Science 320: 784-786.

10. Mabeau S, Fleurence $J(1993)$ Seaweed in food products: biochemical and nutritional aspects. Trends in Food Science \& Technology 4: 103-107.

11. Holdt SL, Kraan S (2011) Bioactive compounds in seaweed: functional food applications and legislation. J Appl Phycol 23: 543-597.
12. Reddy AA (2006) Growth and Instability in Chickpea Production in India: A State Level Analysis. Agricultural Situation in India 230-245

13. Pulses EGo (2012) Report of Expert Group on Pulses. Director, National Centre fo Integrated Pest Management, Indian Council of Agricultural Research, New Delhi.

14. Gupta V, Kumar M, Brahmbhatt H, Reddy CRK, Seth A, et al. (2011) Simultaneous determination of different endogenetic plant growth regulators in common green seaweeds using dispersive liquid-liquid microextraction method. Plant Physiology and Biochemistry 49: 1259-1263.

15. Sridhar S, Rengasamy R (2010) Studies on the effect of seaweed liquid fertilize on the flowering plant Tagetes erecta in field trial. Advances in Bioresearch 1: 29-34

16. Rathore SS, Chaudhary DR, Boricha GN, Ghosh A, Bhatt BP, et al. (2009) Effect of seaweed extract on the growth, yield and nutrient uptake of soybean (Glycine max) under rainfed conditions. S Afr J Bot 75: 351-355.

17. Nissen SJ, Sutter EG (1990) Stability of IAA and IBA in nutrient medium to several tissue culture procedures. HortScience 25: 800-802.

18. Hodson HK, Hamner KC (1971) A Comparison of the Effects of Autoclaved and Nonautoclaved Gibberellic Acid on Lemna perpusilla 6746. Plant Physio 47: 726-728.

19. Ellis RH, Osei-Bonsu K, Roberts EH (1982) The influence of genotype temperature and moisture on seed longevity in chickpea, cowpea and soya bean. Annals of Botany 50: 69-82.

20. Dickie JB, Ellis RH, Kraak HL, Ryder K, Tompsett PB (1990) Temperature and seed storage longevity. Annals of Botany 65: 197-204. 